\title{
自動車用アルミニウム部品の表面処理技術 \\ Surface treatment technology of aluminum part for cars
}

\author{
山口＼cjkstart賢之* \\ Masayuki YAMAGUCHI*
}

\section{1.はじめに}

21 世紀は, 1997 年 12 月に京都で開催された気候変動枠組 条約第 3 回締約国会議（COP3，京都会議）で採択された, 先進国および市場経済移行国の温室効果ガス排出の削減目的 を定めた京都議定書を始めとして，地球温暖化に対し人類一 人一人がどう取り組んで行くかが重要な時代であるといえる。

そういった中で, 自動車に携わるものとしても低燃費化要 求は避けて通れない急務の課題となっている。巷では八イブ リッドや燃料電池のように大きくマスコミ等で取り上げられ ている動力源の低燃費化技術の開発も進められているが，車 体の軽量化が低燃費化之動力性能の向上を両立させるのに不 可欠な技術であることを忘れてはならない。この中で大幅な 軽量化を実現するには, ボディ素材のスチールからアルミニ ウムへの材料置換が一つの有効な手段であった。

ここでは，世界初オールアルミニウムボディを実現した NSXから，スチールボディにアルミニウムパーツを組合せる アルミニウム・スチールハイブリッドボディ（以下ハイブ リッドボディ）である S2000 や最新のレジェンドまでの表面 処理における生産技術的観点を中心とした知見・課題および 今後の展開について述べる。

\section{2. アルミニウムボディ生産ラインの概要}

当初本田技研工業(株は杤木製作所にあった高根沢工場で オールアルミニウムボディからハイブリッドボディまでを生 産していたが，現在では鈴鹿と埼玉の製作所においてハイブ リッドボディを生産している。ここでは，当初生産していた アルミニウムボディ塗装ラインの概要を図 1 に示す。この工 場は 1990 年に量産開始したアルミニウムモノコックボディ NSX の専用工場として立ち上がり，その後ハイブリッドボ ディの生産む行っていた。

基本的にこの工場は, 少量生産機種の生産を行っており, 投資最小を狙った NSX 立ち上がり時のラインコンセプトを ベースに，その後の新機種についても最小の投資で立ち上げ を実施してきた。

その後, ハイブリッドボディ機種の拡大や更なる生産性の 向上を目的に鈴鹿製作所に設備移管された。また埼玉製作所 にも中量生産機種となるレジェンドのハイブリッドボディ生 産設備を導入してきた。

\section{3. アルミニウム素材適用範囲の変化}

当初, オールアルミニウムボディとして NSX を立ち上げて 高い品質を狙ったが，結果的にはアルミニウム材料によりコ ストを圧迫する結果となった。

しかしながら，軽量化による低燃費化は急務の課題であり， 後回しにすることはできない。そこで, 我々は軽量化とコス トを高い次元で両立させるために, 八イブリッドボディの量 産化へと進むことにした。この方向は今後も拡大はあっても 縮小して行くことはないと考えられる。

\section{4. アルミニウムボディの表面処理}

1990 年 8 月より発売を開始した NSX は, オールアルミニ ウムボディにすることにより車体を軽量化し, 加速・ハンド リング性能向上と燃費改善を実現することができた。しかし， アルミニゥムに特徴的な問題として, 塗膜下の糸状腐食や異 種金属との接触部に電位差腐食等が見られた。これらの問題 を種々の表面処理技術と生産技術で解決していくことでオー ルアルミニウムボディからハイブリッドボディの実用化を進 めることができた。

以降の章でそれぞれの代表選手ともいえる NSX とS2000の 量産化検討からの知見を紹介する。

\section{5. オールアルミニウムボディ}

\section{1 表面処理防錆に対する考え方}

NSX のボディに使用されたアルミニウム材料の種類と主目 的を表 1 に示す。

アルミニウムボディの防錆に対する考え方はスチールボ ディと何ら変わることなく, 商品性を損なう表面錆や安全性 を損なう機能錆を防止し，車としての寿命を長く保つことに ある。

しかし，オールアルミニウムボディを開発する上での以下 の問題点があった。

（1）表面錆

・前処理が不十分であることから発生する塗膜密着不良

・チッピング等の塗膜傷およびェッジ部塗膜からの糸錆の広 がり

・外装部品との電位差腐食による塗膜膨れ

*ホンダエンジニアリング株) 5G（９ 321-3395＼cjkstart杤木県芳賀郡芳賀町芳賀台 6-1)。 Honda Engineering Co., Ltd. 5G（6-1, Hagadai, Haga-machi, Haga-gun, Tochigi 321-3395).

受付日：平成 18 年 12 月 19 日 受理日：平成 18 年 3 月 27 日 


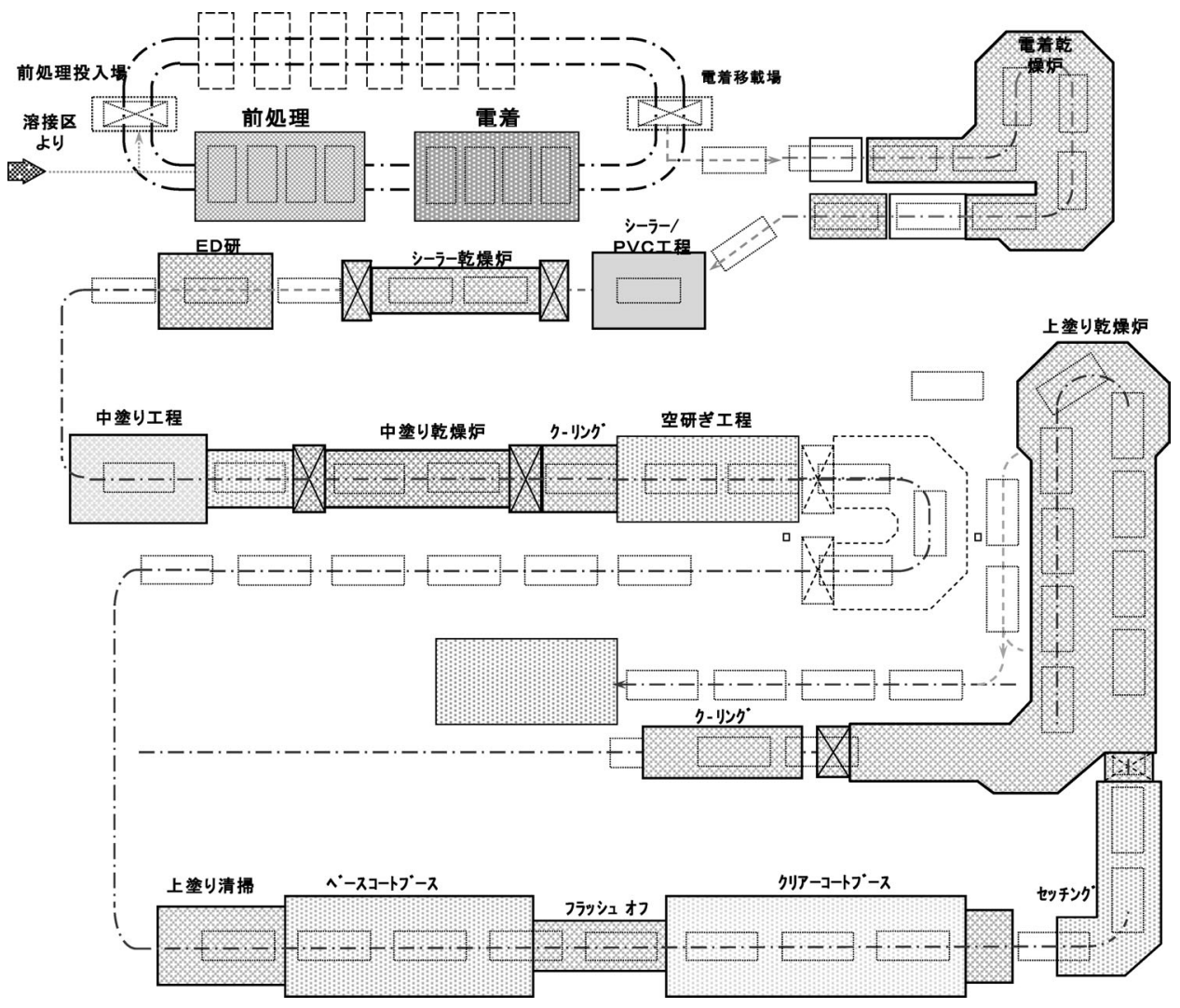

図 1 アルミニウムボディ塗装ライン

表 1 アルミニウム材料種と目的

\begin{tabular}{l|c|c}
\hline \hline ボディ部位 & 材料の種類 & 主目的 \\
\hline パネルアウタ & 6000 系 & 高成形性・高耐食性 \\
パネルインナ & $5052-0$ & 高成形性・高耐食性 \\
骨格 & $5182-0$ & 高強度・高溶接性 \\
サイドシル & 6000 系 & 高押出性・高溶接性 \\
\hline
\end{tabular}

（2）機能錆

・異種金属締結部廻りの電位差腐食

・板合せ部の孔食

我々はこれらの問題点を解決して行くことによって、オー ルアルミニウムボディの実用化を可能とした。

\section{2 前処理システム}

通常アルミニウムの前処理には陽極酸化法や化成皮膜法が 用いられるが，ドアヒンジ等の鉄部品を締結されたアルミニ ウムボディには陽極酸化法は適さないと考えたため, 化成皮 膜法を選択した。

当時, 化成皮膜法としては従来スチールボディに用いられ ていた方法を始めとして数種あったことと, アルミニウム材 料屯最適なものを選択するとの目的から，処理法については， りん酸亜鉛法，りん酸クロメート法，クロム酸クロメート法， およびノンクロム法を検討した。また，部材としては 5000 系 および 6000 系アルミニウム合金で比較した。その結果を表 2 に示す

この結果によりクロム酸クロメート法が最も有効であると
判断した ${ }^{1) 2}$ （図 2, 図 3)。

\section{6. ハイブリッドボディ}

\section{1 コストバリューある軽量化}

NSX で採用したオールアルミニウムボディにおいて大幅な 車体の軽量化を達成することで, 動力性能・操縦安定性はむ とより燃費向上による環境改善に対して高い貢献ができた。 残念ながらその反面かなりのコスト上昇となり，適用できる 車種が極めて限られることとなった。しかし, 環境改善等の 目的のためには, ボディの軽量化は不可避であり, そのため のアルミニウム化を少しでも大量生産車種にコスト上昇を抑 えながら，かつ軽量化効果を生み出せる部位に適用するハイ ブリッドボディを展開することにした。

そこで, NSXの量産実績をふまえ, 八イブリッドボディ表 面処理生産技術を開発したので，以下に述べることとする。

\section{2 表面処理方法の選択}

アルミニウムボディの表面処理については，5.2で述べた ようにクロム酸クロメート処理が最屯有効であることがわ かっているが, スチールとの同時処理を考えると, ライン汎 用性屯含めて，りん酸亜鉛処理が優れていると言える。しか し, 従来のスチールだけの処理方法のままではアルミニウム の耐食性に関して, りん酸亜鉛処理はクロム酸クロメート処 理に劣っている。

そこで，アルミニウム・スチール同時処理可能なりん酸亜 鉛処理による耐食性向上を検討した。

\section{3 混合りん酸亜鉛処理}

我々が採用している 6000 系アルミニウム合金について，り 


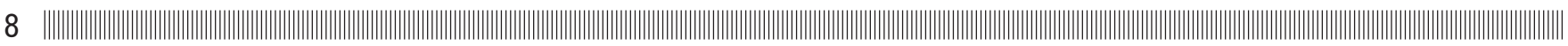

表 2 化成皮膜法に対する塗膜性能

\begin{tabular}{|c|c|c|c|c|c|c|c|c|c|}
\hline アルミニウム素材 & \multicolumn{4}{|c|}{5000 系アルミニウム合金 } & \multicolumn{4}{|c|}{6000 系アルミニウム合金 } & \multirow{3}{*}{ テスト評価内容 } \\
\hline 化成皮膜 & $\begin{array}{l}\text { りん酸 } \\
\text { 亜鈆 }\end{array}$ & $\begin{array}{c}\text { りん酸 } \\
\text { クロメート }\end{array}$ & $\begin{array}{c}\text { クロム酸 } \\
\text { クロメート }\end{array}$ & $\begin{array}{l}\text { ノン } \\
\text { クロム }\end{array}$ & $\begin{array}{l}\text { りん酸 } \\
\text { 亜鉛 }\end{array}$ & $\begin{array}{c}\text { りん酸 } \\
\text { クロメート }\end{array}$ & $\begin{array}{l}\text { クロム酸 } \\
\text { クロメート }\end{array}$ & $\begin{array}{l}\text { ノン } \\
\text { クロム }\end{array}$ & \\
\hline テスト項目 & \multicolumn{8}{|c|}{ 圧膜カチオン電着 + 中塗り + 上塗り } & \\
\hline $\begin{array}{l}\text { (1)耐水性 } \\
\text { (2)耐湿性 }\end{array}$ & $\begin{array}{l}\text { (1) } \\
\text { (0) }\end{array}$ & $\begin{array}{l}\text { (a) } \\
\text { (0) }\end{array}$ & $\begin{array}{l}\text { (0) } \\
\text { (0) }\end{array}$ & $\begin{array}{l}\text { (a) } \\
\text { (0) }\end{array}$ & $\begin{array}{l}\text { (a) } \\
\text { (0) }\end{array}$ & $\begin{array}{l}\text { (a) } \\
\text { (0) }\end{array}$ & $\begin{array}{l}\text { (0) } \\
\text { (0) }\end{array}$ & $\begin{array}{l}\text { (a) } \\
\text { (a) }\end{array}$ & $\begin{array}{l}\text { 碁盤目カット部を } \\
\text { テープ剥離したと } \\
\text { きの塗膜残存状況 }\end{array}$ \\
\hline $\begin{array}{l}\text { (3)耐塩温水性 } \\
\text { (4)耐糸錆性 } \\
\text { (5)塩水噴霧試験 } \\
\text { (6)複合腐食試験 }\end{array}$ & $\begin{array}{l}0 \\
\times \\
(0) \\
(0)\end{array}$ & $\begin{array}{l}\text { ()) } \\
0\end{array}$ & $\begin{array}{l}\text { () } \\
\text { () } \\
\text { ()) }\end{array}$ & $\begin{array}{l}x \\
0 \\
0 \\
0\end{array}$ & $\begin{array}{l}X \\
\times \\
0\end{array}$ & $\begin{array}{l}0 \\
\times \\
\times \\
X\end{array}$ & $\begin{array}{l}0 \\
\times \\
0 \\
0\end{array}$ & $\begin{array}{l}\times \\
\times \\
\times \\
\times\end{array}$ & $\begin{array}{l}\text { カット部からの } \\
\text { 錆広がり }\end{array}$ \\
\hline
\end{tabular}

\begin{tabular}{c|c|c|c|c|c}
\hline \hline 主要元素 & $\mathrm{Cu}$ & $\mathrm{Mg}$ & $\mathrm{Si}$ & $\mathrm{Fe}$ & $\mathrm{Mn}$ \\
\hline 5000 系アルミニウム合金 & $\begin{array}{c}0.15 \text { 以下 } \\
6000 \text { 系アルミニウム合金 }\end{array}$ & $\begin{array}{c}4.0 \sim 5.0 \\
0.45\end{array}$ & $\begin{array}{c}0.2 \text { 以下 } \\
1.70\end{array}$ & $\begin{array}{c}0.35 \text { 以下 } \\
0.17\end{array}$ & $\begin{array}{c}0.2 \sim 0.5 \\
0.17\end{array}$ \\
\hline
\end{tabular}

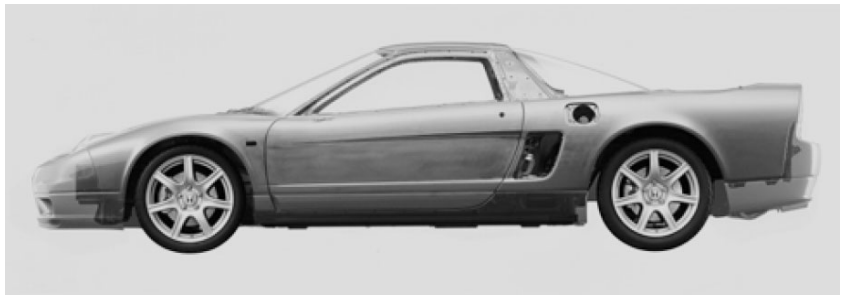

図 2 オールアルミニウムボディの NSX

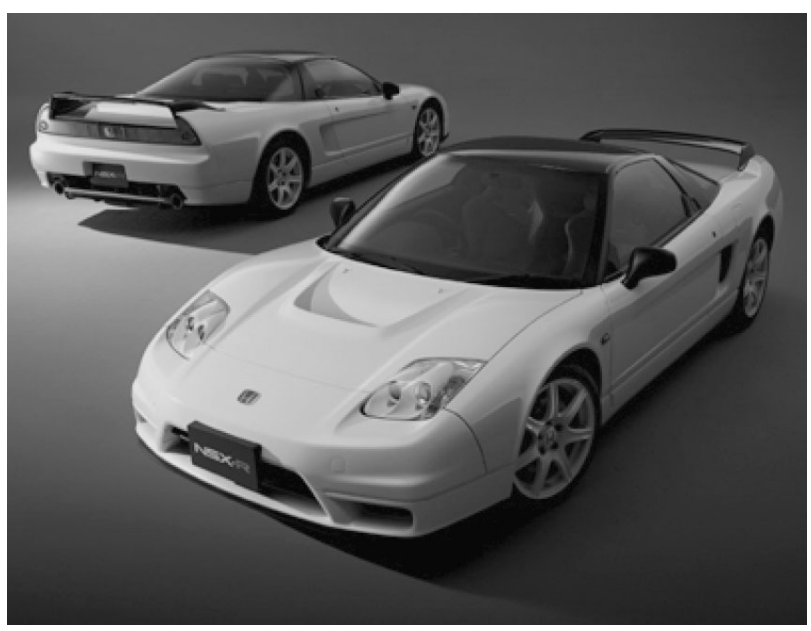

図 3 NSX

ん酸亜鉛皮膜付着量と糸錆長さの関係を図 4 に示す。

これより, 皮膜付着量が $1.0 \mathrm{~g} / \mathrm{m}^{2}$ 以上であればクロム酸クロ メート皮膜と同等の性能を有することがわかる。

スチール上の皮膜析出反応は次式に示した通りである。
$\mathrm{Fe} \rightarrow \mathrm{Fe}_{2}^{+}+2 \mathrm{e}^{-}$
（1）アノード反応
$2 \mathrm{H}^{+}+2 \mathrm{e}^{-} \rightarrow \mathrm{H}_{2} \uparrow$
（2）カソード反応

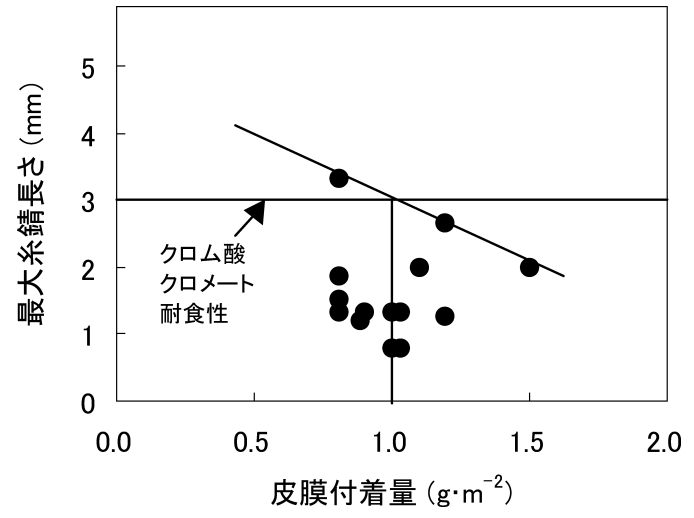

図 4 りん酸亜鉛皮膜付着量と糸錆長さ

$$
\begin{aligned}
& 3 \mathrm{Zn}\left(\mathrm{H}_{2} \mathrm{PO}_{4}\right)_{2} \rightarrow \mathrm{Zn}_{3}\left(\mathrm{PO}_{4}\right)_{2}+4 \mathrm{H}_{3} \mathrm{PO}_{4} \text { (3) 皮膜析出反応 } \\
& 2 \mathrm{Zn}\left(\mathrm{H}_{2} \mathrm{PO}_{4}\right)_{2}+\mathrm{Fe}\left(\mathrm{H}_{2} \mathrm{PO}_{4}\right)_{2} \\
& \quad \rightarrow \mathrm{Zn}_{2} \mathrm{Fe}\left(\mathrm{PO}_{4}\right)_{2}+4 \mathrm{H}_{3} \mathrm{PO}_{4} \quad \text { (4) 皮膜析出反応 }
\end{aligned}
$$

鋼板用のりん酸亜鉛処理液をそのまま用いてもアルミニウ ムはエッチングされにくいために，りん酸亜鉛皮膜の析出反 応は起こりにくい。

そこでふっ素イオンを添加することでアルミニウムのエッ チングを促進し，りん酸亜鉛皮膜を析出しやすくした。

$$
2 \mathrm{Al}+6 \mathrm{HF} \rightarrow 2 \mathrm{AlF}_{3}+3 \mathrm{H}_{2} \uparrow
$$

（5）アルミニウム表面エッチング

ただし，アルミニウムイオンが蓄積すると表面処理効果を阻 害してしまうので, スラッジ化させる必要がある。

$$
\mathrm{Al}^{3+}+3 \mathrm{Na}^{+}+6 \mathrm{~F}^{-} \rightarrow \mathrm{Na}_{3} \mathrm{AlF}_{6}
$$

（6）アルミニウムイオンのスラッジ化 


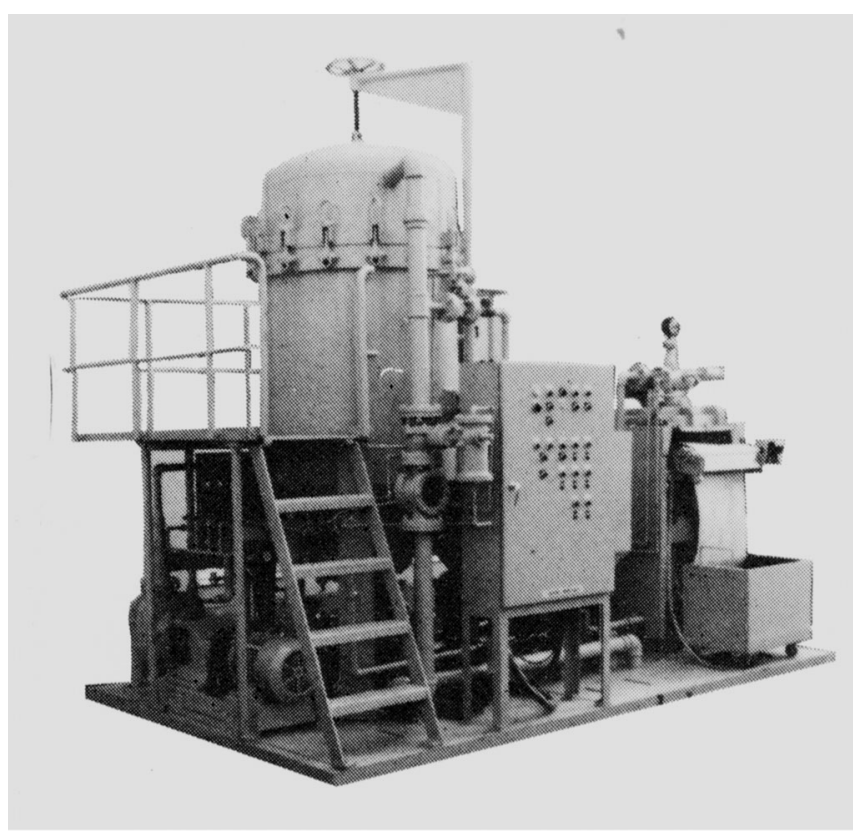

図 5 全量ろ過システム外観

また，濃度管理だけではふっ素イオンとアルミニウムイオ ンのスラリーが浴液中に充満する。このスラリーは, 浴液内 を浮遊し，ボディを処理する際外観品質に悪い影響を与える ので, 逐次除去しなければならない。通常のスラリーはその 重さにより沈殿スラッジ化させることができるため, 濃縮除 去万過が容易であるが，この系では濃縮させること自体が容 易でないため，全量ろ過システムを採用した。

このシステムの外観は図 5 に示しているが，そのろ過シス テムは，図 6 に表したように，フィル夕の目詰まり等でろ過 効率が低下すると自動的に逆洗をし, 長期間ろ過効果を持続 させるようにしている。

これによって, 量産性を有するアルミニウム表面処理シス テムができた。

また，アルミニウムとスチールの同時処理をクロム酸クロ メートで実施した場合は，アルミニウム部の表面にごくわず かではあるが電気抵抗が高い層が生じ，スチールと比較して 電着の付きが悪い（膜厚が低減する）ことがわかった。この 問題む, りん酸覀鉛処理を用いることで解決したことを報告 しておく。

\section{4 密着性と防錆性}

前項で述べたように，ふっ素イオンの添加と全量ろ過によ り耐食性表面処理ができるようになったが，このふっ素イオ ン濃度が高すぎると塗膜の密着性が低下することも知られて いる。これは，アルミニウム材の表面に付着したふっ素化合 物が塗膜の密着性を阻害するためと考えられている。密着性 を向上するために，りん酸亜鉛処理の後工程でクロムリンス を実施し，ふっ素化合物を除去する必要がある。図７にクロ ムリンス後処理を施さない場合と施した場合の，耐水二次密 着性試験結果を示す。クロムリンス後処理により，耐水二次 密着性が改善されているのがわかる。

また, ふっ素イオンを添加しても, アルミニウム材の研削 面では, 研削溝の部分が十分に皮膜で被覆されにくく, その

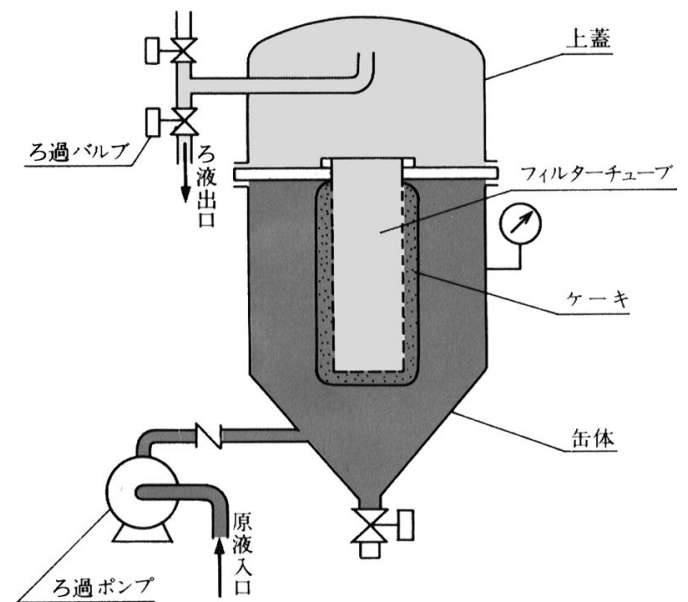

ろ 過

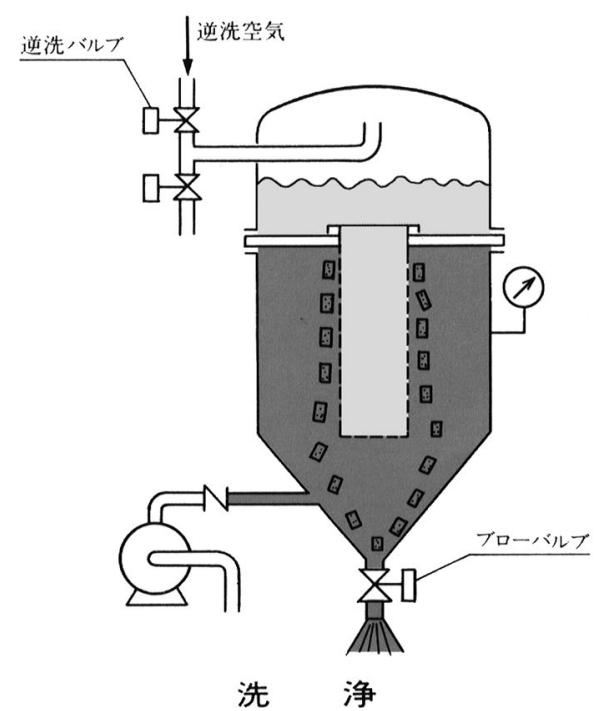

図 6 万過・逆洗システム

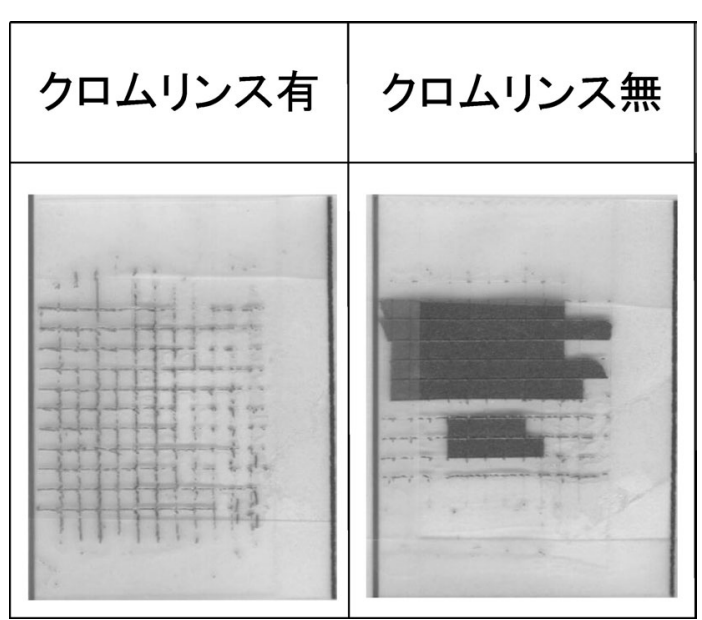

図７クロムリンス有無での耐水二次密着結果

結果，研削面は耐糸錆性が低下するという問題が生じる。こ れに対して, 電着塗料中にクロム系防食顔料を添加すると耐 糸錆性が改善されることが知られている。図 8 に, クロム系 防食顔料の効果を示す。 


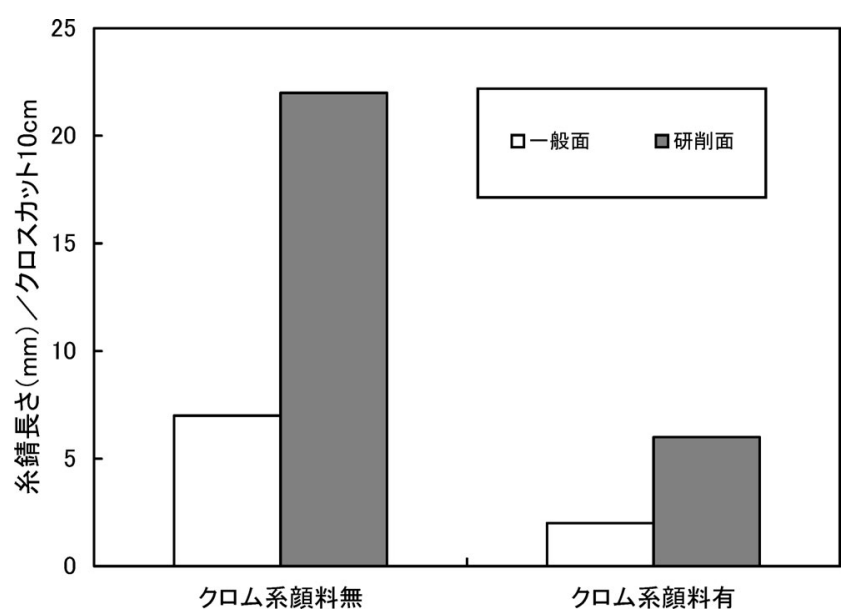

図 8 クロム系顔料有無による糸錆長さ

以上のように，従来のアルミニウム・鋼板混合処理用りん 酸亜鉛処理は，塗膜の密着性や耐糸錆性を良好に保つため に，第 1 ステップとして工程中にクロムを含有した材料にて 防錆性を確保した。

\section{5 防錆性能を低下させずにクロムフリー化}

一方, クロムを含む表面処理は環境に対する悪影響が懸念 されることや，排水処理コストが増加することから，その次 のステップとしてクロムフリー化に取り組んだ。現に 6 価ク ロムについては 2006 年 7 月からは EU の RoHS 指令（特定有 害物質使用禁止指令）でさらに規制が強まり，2007 年 7 月か らは ELV 規制（使用済み自動車 End of Life Vehicle）で使用 禁止になることが決まっている。

クロムを使用せずに同等の防錆性能を発揮させる糸口とし て, りん酸亜鉛析出の化学反応をより活性化させる方向で取 り組んで行った。その反応促進剤として，りん酸亜鉛処理液 にふっ素打よび鉄錯体化合物を添加する方法を開発し，塗装 工程よりクロムを含む材料を廃止することができたので以下 に述べる。

クロムリンス後処理や電着塗料中のクロム系防食顔料を使 用せずにアルミニウム材の塗装後耐食性を確保するためには, りん酸亜鉛処理液の反応性を高めることにより，ち密で均一 なりん酸亜鉛皮膜を形成し被覆性（素材表面をりん酸覀鉛皮 膜が被覆する割合）を向上させることが必要である。一般に, 酸性液中のアルミニゥムのエッチング促進剤として，また， 鋼鈑表面にち密で均一なりん酸亜鉛皮膜を形成させるために, 鉄イオン $\left(\mathrm{Fe}^{3+}\right)$ の効果が知られている ${ }^{3), 4}$ 。

しかし，鉄イオンはりん酸鉄としてスラッジ化するために 錯体化することで反応性の向上を図った結果, 次の成果が得 られることがわかった。

（1）鉄錯体化合物の添加により, りん酸亜鉛の析出反応が 促進され，アルミニウム材に対するりん酸亜鉛皮膜の被覆性 が向上した。従来りん酸亜鉛皮膜が析出しにくかった研削部 にも，りん酸亜鉛皮膜を析出させることが可能になった。

（2）この結果，塗膜密着性に悪影響を与える Al-F 化合物 の析出を抑制することができ，クロムリンス後処理がなくて あ十分な耐水二次密着性が確保できることがわかった。また, 従来の処理と比較して耐糸錆性も向上した。

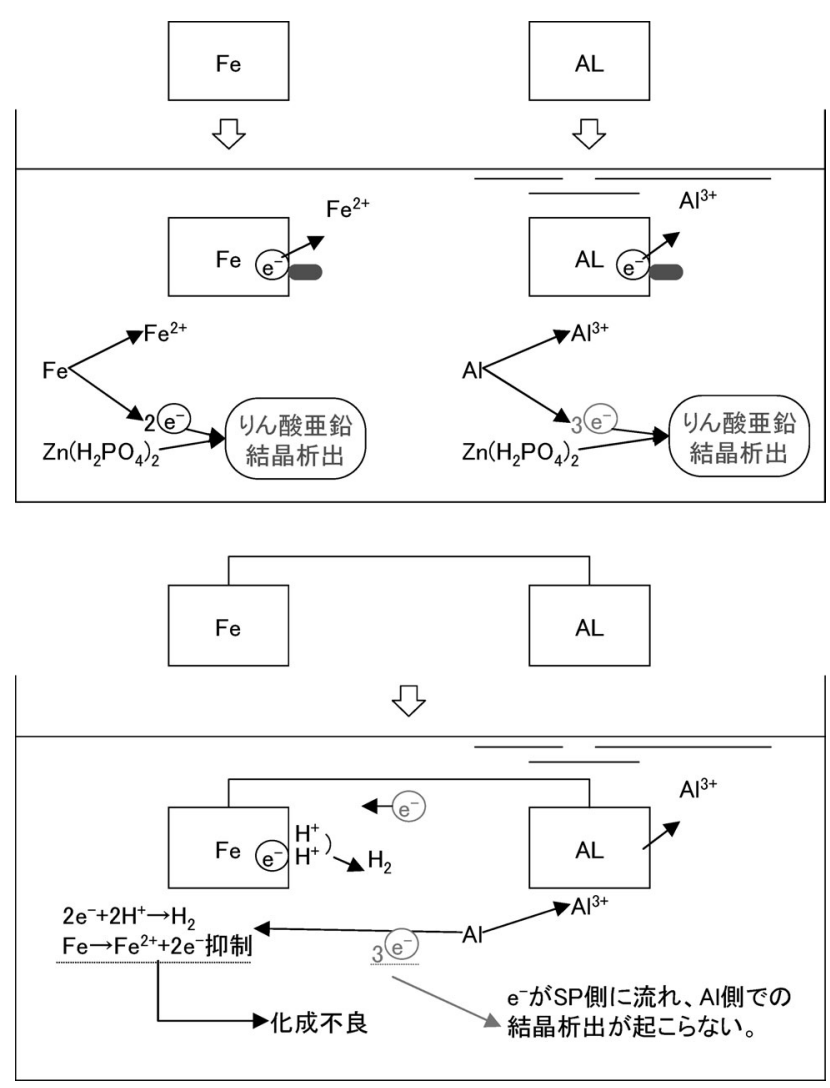

図 9 表面処理不良発生メカニズム

（3）これらの結果, 電着塗料中にクロム系防食顔料を添加 しなくても十分な耐糸錆性が確保できることがわかった。 以上の内容により第 2 ステップとしてクロムフリー表面処 理システムを開発することができた ${ }^{5)}$ 。

\section{6 アルミニウム・スチール接触部防錆処理不良対策}

前章の方法で, アルミニウム・スチールともに十分な表面 処理効果が得られることがわかったが, それらを接触した場 合, 言い換えれば電気的に導通させたまま同時に処理をさせ ようとすると, 図 9 に表したメカニズムによりアルミニウム 側ではりん酸亜鉛の析出に必要な $\mathrm{H}^{+}$の発生が阻害され皮膜 はほとんど生成せず，一方スチール側では $\mathrm{H}_{2}$ の発生でりん 酸亜鉛は析出するが, 活性面が露出されにくいために析出し たりん酸亜鉛はスラッジとして沈降してしまい, 十分な皮膜 が得られなくなってしまう。

これは合金化溶融亜鉛めっきされているスチールとアルミ ニウムの接触の場合では, スチール側はりん酸亜鉛皮膜が形 成されるものの, やはりアルミニウム側は皮膜をほとんど生 成できない。

これらの事象を解決するためには, 現状アルミニウムとス チールの接触部をなくす，すなわち絶縁しなければならない ことがわかった。

したがって, 表面処理工程前に図 10 に示すような絶縁処 置をしておかなければならないが, 次工程の電着塗装におい ては, 通常ボディハンガーでアースをとっているため, 絶縁 状態にある素材（S2000の場合アルミニウムフード）の導通 を電着工程投入前に実施する必要がある。 


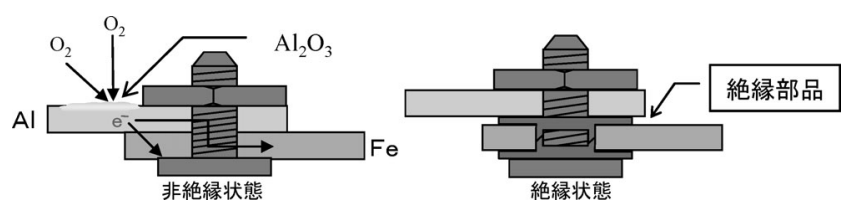

図 10 アルミニウムとスチールの絶縁例

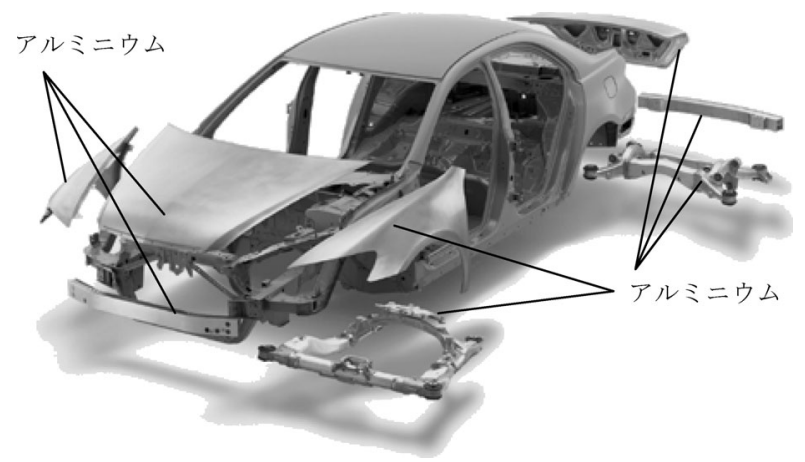

図 11 ハイブリッドボディのレジェンド

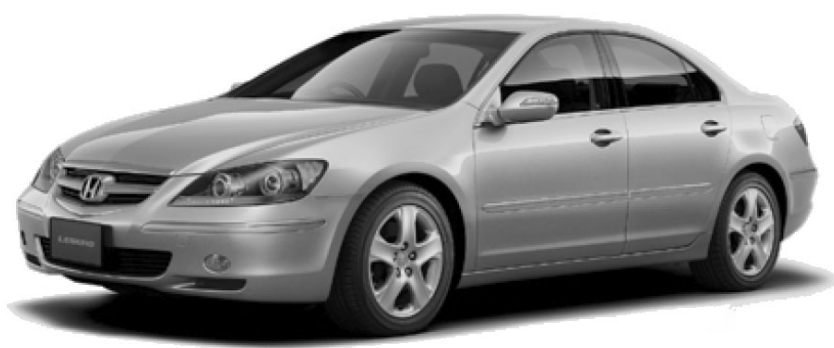

図 12 レジェンド

これは，現在生産されている比較的少・中量生産機種の量 産時は大きな課題とはいえないかもしれないが，大量生産に おいては大きな課題になってくる。

しかし，課題はあるもののレベルの高い同時表面処理技術 を確立できたことで，S2000（図 11）やレジェンド（図 12） のようなハイブリッド車の量産が可能となった。

また，表面処理材料の改良による皮膜形成能力の向上屯図 られてきており, やがて絶縁処置も不要になる日は近いと考 えられる。

\section{7. 軽量化新素材に対する新製法の変遷}

\section{1 高温成形のための酸洗処理}

S2000については，今まで述べてきた表面処理のほかに， さらに別の表面処理技術が適用されている。

それは, 車体本体ではなくオプションとして用意されてい るハードトップルーフに関してのあのである。このハード トップは車体本体の軽量化に対する影響を最小限とし，かつ コストも最小限にするため一体成形を採用した ${ }^{6)}$ 。

そのために,

(1)高速で成形が可能であること

(2)商品性要件（材料強度，外観品質等）を満足すること などから，展性の高い 5000 系のアルミニウムを素材として材 料開発をしたが, 高温高圧成形条件において, 表面に酸化皮

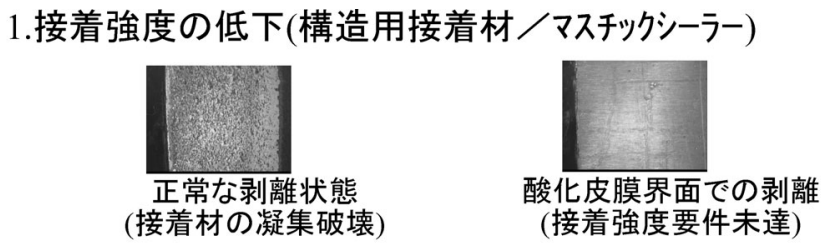

\section{2.塗装密着性能の低下(耐衝撃/屈曲性)}

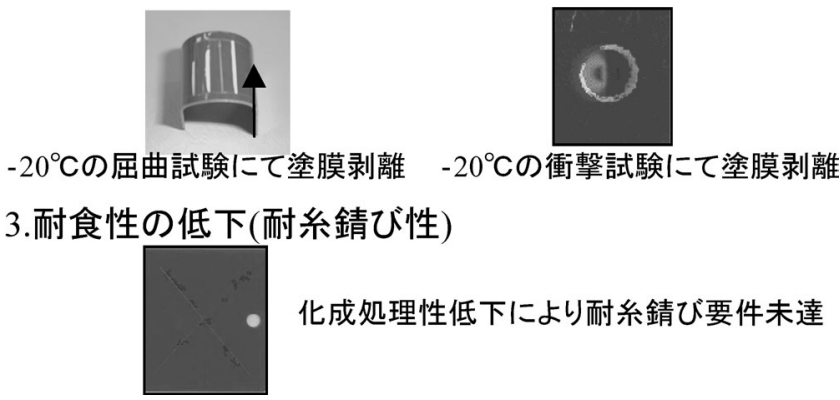

図 13 高温高圧成形における塗膜性能の低下

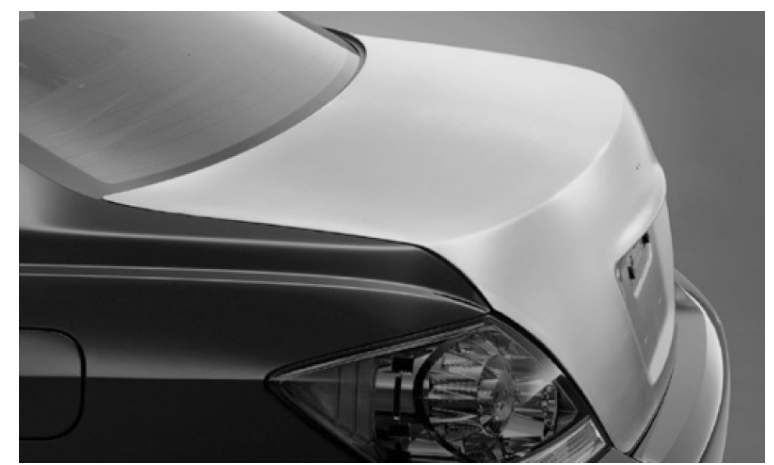

図 14 レジェンドのトランクリッド

膜の生成が見られた。

この酸化皮膜を生成したままでは，図 13 に示したように 諸性能が低下してしまうために，除去する必要があることが わかった。

そこで, 成形後にりん酸系溶液での酸化皮膜除去処理工程 を設定し良好なりん酸亜鉛皮膜の析出を実現した。

7.2 高温成形高速化による酸洗フリー化

しかし，ハードトップよりはるかに生産量の多いレジェン ドのフェンダとトランク（図 14）のアルミニウム化を実現す るためには，さらなる高速な高温高圧成形が必要とされた。 それを試行錯誤の上，プレス材の予熱条件・成形条件とモデ ル形状それぞれの最適化を図った結果 ${ }^{7)}$, 予熱サイクルの短 縮化とともに酸化皮膜成長の抑制屯同時に達成され, 酸洗フ リー化をむ実現することができた ${ }^{8)}$ 。

\section{8. アルミニウム素材の塗装外観}

車体の塗装は静電塗装（塗料に電圧を印可して静電気力で 塗着させる方法）で行われる場合が多い。

また，わずかな塗装条件の違いで仕上がり外観に大きな影 響が出やすい屯のである。

特に素材がアルミニウム・スチールのハイブリッドボディ となると，測定温度にもよるが、アルミニウムはスチールに 


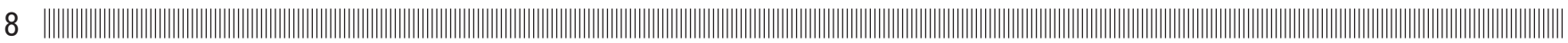

表 3 アルミニウムとスチールでの発色の差

\begin{tabular}{r|c|c|c|c}
\hline \hline & $\Delta \mathrm{E}$ & $\Delta \mathrm{L}$ & $\Delta \mathrm{a}$ & $\Delta \mathrm{b}$ \\
\hline $15^{\circ}$ & $\bigcirc$ & $\bigcirc$ & $\bigcirc$ & $\bigcirc$ \\
$45^{\circ}$ & $\bigcirc$ & $\bigcirc$ & $\bigcirc$ & $\bigcirc$ \\
$110^{\circ}$ & $\bigcirc$ & $\bigcirc$ & $\bigcirc$ & $\bigcirc$ \\
\hline
\end{tabular}

比べて電気抵抗はおよそ 4 分の 1 であるために，素材の差に よる電気抵抗値の違いが, 静電塗着状態の差を生じ外観品 質，特に発色に影響を与える恐れがあった。

また，素材差による表面硬度の違いから，傷のつきやすさ， 傷の深さ等の差が，やはり外観品質，特に平滑性に影響する のではないかと考えた。

そこで我々が実際に静電塗装テストに扔いて, 発色に差が あるかどうかを確認した結果を表 3 に示す。目視に近い色評 価をするために光源正反射光に対して光源側に $15 / 45 / 110^{\circ}$ の 3 角度での反射光を分光測定している。

この結果を見ると, 基本的には量産ラインのばらつきの範 囲内であり, 当初心配していた素材での静電塗着状態の違い による発色の差への影響はない之判断できた。

しかし, 素材の表面硬度の違いは, 溶接での仕上げ研削の 際により深く削れてしまい，量産工程での同時研削プロセス では, スチール系品質出しのための研削条件でアルミニウム を研削してしまい，傷のつき方か激しくなってしまう。その ために，平滑性を阻害する表面粗度になってしまう場合があ り, 該当工程での作業は, スチールボディに比較して, 慎重 な作業が求められる。図 15 亿表面粗度デー夕を示す。

さらにレジェンドでは, 極めて精度の高い成形性と図 16 で表している塗膜構成の適正化によって従来にない超高外観 を実現することができた。

\section{9. まと め}

過去 15 年間にわたって, アルミニウムの表面処理に関し て, 以上のような着想で課題の対応をしてきた結果, 我々は, 高品質のオールアルミニウムボディからハイブリッドボディ まで自由に生産できるようになった。コスト面からハイブ リッド機種が中心になってきているが，オールアルミニウム ボディの生産技術は，今であインサイトに流用され，世界で あ類を見ない低燃費自動車を生み出している（図 17）。

1 章であ述べたが, 今後自動車に求められる軽量化の近道 として考えられるのは，アルミニウム素材等のスチールに 取って代わ机る素材である。しかしながら, 軽量化を追い求 めるのみで，いたずらにコストを上昇させてしまうようでは, 売り手側の都合だけで，買い手側，すなわちお客様に迷惑を かけてしまうことになる。したがって，我々自動車を製造す る側も，いかにコストを上げずに軽量化していけるかを常に 模索しながら進んでいる。

かつて，バブルと呼ばれた時代は，付加価值があれば価格 が上昇していてもニーズがあり，世の中に浸透していった。 しかし，屯はやそのような安易な技術開発は許されない状況 にあり, 同じコスト, 可能であれば更に安いコストでより高

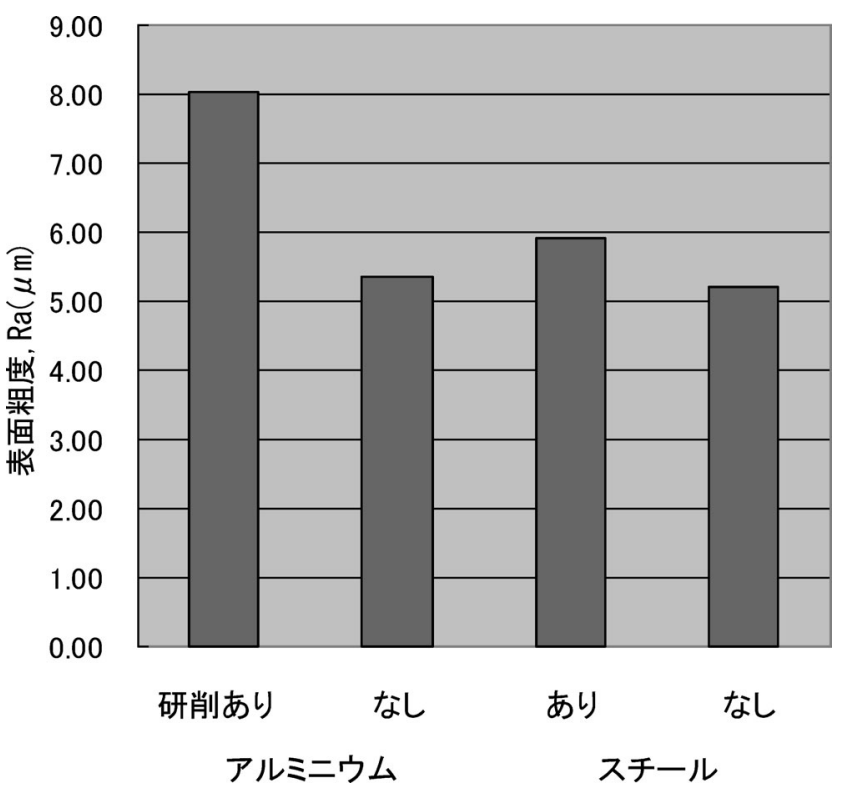

図 15 アルミニウムとスチールの表面粗度

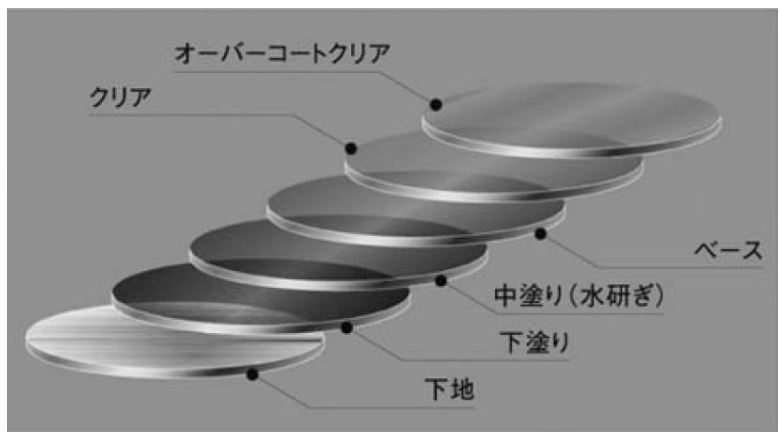

図 16 レジェンドの超高外観塗装

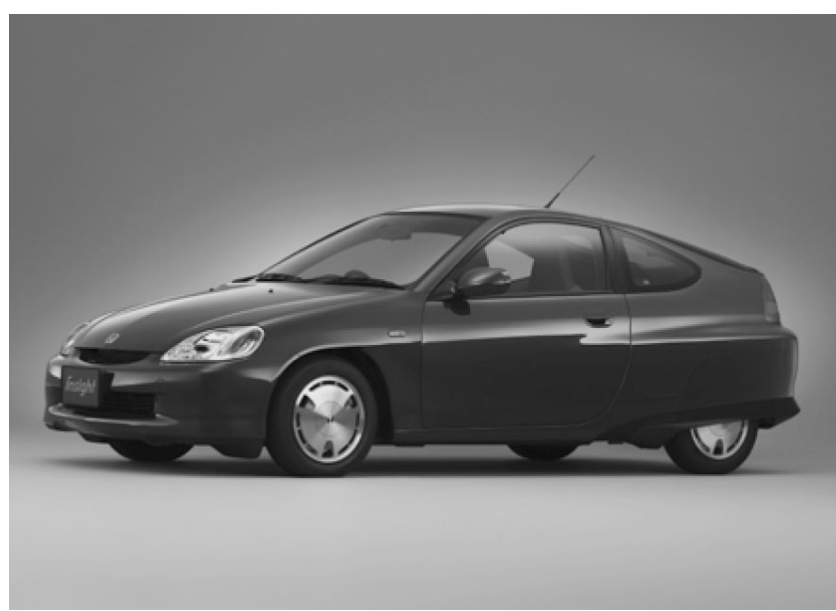

図 17 オールアルミニウムボディ（一部樹脂外板）のイ ンサイト

い付加価值が求められている。

近い将来にアルミニウムをボディに適用する場合に，今回 述べさせていただいた課題を少しでもなくすことができる， 生産技術でのコス卜上昇を招かない軽量素材の出現を心から 待ち望んでいる。 
||||||||||||||||||||||||||||||||||||||||||||||||||||||||||||||||||||||||||||||||||||||||||||||||||||||||||||||||||||||||||||||||||||||||||||||||||||||||||||||||||||||||||||||||||||||||||||||||||||||||||||||||||||||||||||||||||||||||||||||||||||||||||||||||||||||||||||||||| 8

表面処理材料ではすでに開発が始まっているが，素材を選 ばない防錆処理技術の実現なども待たれている。

今後の技術の進化で, 素材と表面処理材料・工程のコラボ レーションでよりリーズナブルな価格展開・競争力を持つ製 品を具現化することができると信じている。

\section{参 考 文 献}

1）小松泰典，鈴木英治，宮崎勝男，西野俊哉：NSX 用オールア ルミニウムボディの表面処理・塗装技術，Honda R\&D Technical Review, Vol. 3 (1991).

2）小松泰典，鈴木英治，宮崎勝男，西野俊哉：NSX 用オールア ルミニウムボディの表面処理・防錆技術，自動車技術会，Vol. 45, No. 6 (1991).
3）山添勝芳，池田 哲，安原清忠：特開昭 61-106783（1986）.

4）小浦延幸, 関口 攻：ACインピーダンス法を用いた酸性浴中 の Al の化学エッチング機構の解析，表面技術，43（1992）, 205-210.

5）西野俊哉, 和泉浩一郎：アルミニウムボデーのためのクロムフ リー表面処理システムの開発, Honda R\&D Technical Review Vol. 13 (2001).

6）横山 鎮，渡辺二郎，奥中啓之，宮岡博也：アルミ合金超塑性 材の自動車・二輪車への適用之今後の展開, 素形材, 11 月号 (2000).

7）木山 啓, 丸山 学, 中尾敬一郎, 中川義明 : 第 55 回塑性加 工連合講演論文集，(2004），217.

8）齋藤和也, 横山 鎮, 迴 秀夫, 渡邊二郎 : 第 70 回型技術セ ミナー，型技術協会，(2005)，1. 